\title{
婎產婦の栄養調查
}

\section{The Nutrition Survey of Pregnant and Lactating Women}

国立栄養研究所調査統計部 (Division of Survəy and Statistics, National Institute of Nutrition)

$$
\text { 磯部しづ子 (S. Isobe) 松野信郎 (N. Matuno) }
$$

The nutrition survey on 14 Pregnant and 2 Lactating women was carried out in order to know how much iron ingested by them, as well as other nutrient intake.

The iron intake was abserved both by calculating from the Food Composition table (revised in 1954) and by chemically analyzing.

The results were that there was found no significant difference between calculated and analyz $ə d$ valu es except concerning figures of side-tables.

The other nutrient intake was not adequate on an average, compared with the Recommended Dietary allowance for pregnant and lactating womeu in Japan.

はしがき 微量栄養素, 特!こ無機質の摂取量が種々論議されているとき, 妊産婦の鉄の摂取量を知ること ね目的として，その栄養実態調査を行つた。

對象 東京都新宿区牛込保健所管内の妊婦 14 名之授乳婦 2 名, 計16名。それを妊娠月数!ニよつて分けてみ ると第 1 表のよう!こなる。

調查の侍期 昭和 28 年 9 月中旬より 10月上旬! こ亘る期間! 1 世帯 3 日間宛。

調㚗方法 妊産婦の家庭を戸別訪問し，所定の調査表に: 3 日間の食物量を詳細に二記入せしめた。調査日の 中 1 日分だけ実際摂取した食物と同量のもの些提出サしめ, それを分析して鉄の含有量を定量した, 鉄の定 量!よオルトフエナンスロリン法によつた。

集計方法 記録にこよる食物量から試料提出の日の鉄の摄取量な改訂日本食品標準成分表により算出して, 定量值と比較し，同時に 3 日間の栄養摂取量学計算した。

調㚗成績 鉄の実測値と計算値との比較!第 2 表に二示す通りである。即ち主食と副食と!分けてそれぞれ 比較するに, 妊娠後期で平均主食が実測值は $4.4 \mathrm{mg}$, 計算值は $5.2 \mathrm{mg}$ となり, 副食はは実測值が $12 \cdot 6 \mathrm{mg}$, 計算 值が8.2mg，合計では夫々 $17.0 \mathrm{mg}, 13.4 \mathrm{mg}$ となつている。

この実測値と計算值の差の有意性を検定してみると， $5 \%$ の危険率にこ於て副食には有意の差が認められた が，主食及び 1 日合計としては差があるとは認められなかつた。

妊娠前期及び授乳期!は何れも例数が少く, 確実なことは云えないが, 全体としては実測值計算值の間!こ大 した差はないようである。

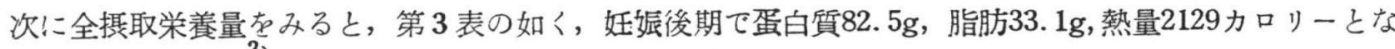
り, これを所要量の蛋白質 $95 \mathrm{~g}$, 熱量2700カロリー!に比較するとはるかに少いように思われる。前期! 2 例 に過ぎないが，その平均は後期よりはるか!こよく，所要量蛋白質 $85 \mathrm{~g}$, 熱量2400カロリーを上廻つている。 授乳期は所要量蛋白質 $100 \mathrm{~g}$ ，熱量3000カロリーには及ばなようである。その他の栄湌素もすへて所要量 に達していない。特にビタミン類は調理!こよる損失㕝慮すれば不足量が大きい。

総括 昭和 28 年の 9 月中旬より10月上旬にこかけて妊産婦の栄養調查を行つた。鉄の摄取量につき, 計算值 と実測值と老推計学的に比較してみると, 副食には差があり, 主食と 1 日分合計には差が認められなかつた。 
第 1 表 対 象

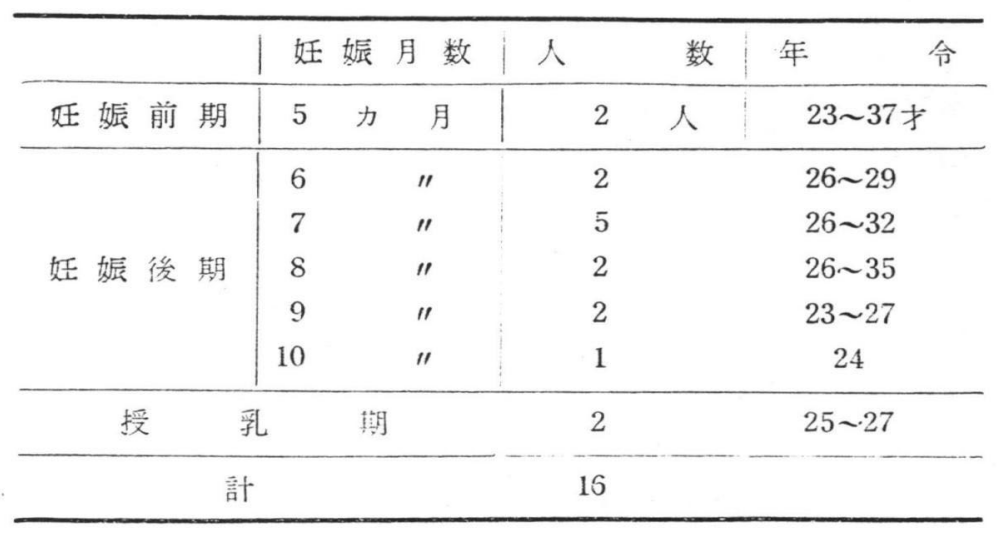

第 2 表 鉄掑取量の計算值と実側值との比較 (単位: $\mathrm{mg}$ )

\begin{tabular}{|c|c|c|c|c|c|c|c|}
\hline \multirow{2}{*}{ 区 分 } & \multirow{2}{*}{ No. } & 主 & 食 & \multicolumn{2}{|l|}{ 副 } & 1 日 & 合 計 \\
\hline & & 実測 值! & 計 算 值 & 実 測 值 & 計 算 值 & 実 測 值 & 計 算 值 \\
\hline \multirow{7}{*}{ 妊 } & 1 & 5.8 & 2.9 & 3.7 & 3.5 & 14.5 & 6.4 \\
\hline & 2 & 2.5 & 4.2 & 15.6 & 8.2 & 18.1 & 12.4 \\
\hline & 3 & 2.2 & 1.7 & 14.6 & 6.1 & 16.8 & 7.8 \\
\hline & 4 & 3.8 & 5.3 & 17.4 & 15.3 & 21.2 & 20.6 \\
\hline & 5 & 5.5 & 3.2 & 17.1 & 7.0 & 22.6 & 10.2 \\
\hline & 6 & 4.5 & 2.8 & 11.3 & 5.2 & 15.8 & 8.0 \\
\hline & 7 & 1.5 & 3.5 & 9.4 & 3.9 & 10.9 & 7.4 \\
\hline \multirow[t]{2}{*}{ 娠 } & 8 & 6.0 & 3.7 & 2.2 & 10.2 & 8.2 & 13.9 \\
\hline & 9 & 7.4 & 8.3 & 15.0 & 20.2 & 22.4 & 28.5 \\
\hline \multirow{3}{*}{ 後 } & 10 & 2.8 & 5.3 & 13.1 & 3.7 & 15.9 & 9.0 \\
\hline & 11 & 5.1 & 3.1 & 15.7 & 10.1 & 20.8 & 1.3. 2 \\
\hline & 12 & 5.7 & 18.4 & 10.7 & 5.2 & 16.4 & 23.6 \\
\hline \multirow{2}{*}{ 期 } & 平均 & $4.4 \pm 1.2$ & $5.2 \pm 2.8$ & $12.6 \pm 2.8$ & $8.2 \pm 3.2$ & $17.0 \pm 3.5$ & $13.4 \pm 4.5$ \\
\hline & $\begin{array}{l}\text { 差 の } \\
\text { 有意性 }\end{array}$ & $(\alpha=0.05)$ & & \multicolumn{2}{|c|}{+} & \multicolumn{2}{|c|}{-} \\
\hline \multirow{3}{*}{$\begin{array}{l}\text { 妊 } \\
\text { 娠 } \\
\text { 前 } \\
\text { 期 }\end{array}$} & 13 & 5.5 & 2.8 & 5.4 & 4.0 & 10.9 & 6.8 \\
\hline & 14 & 3.4 & 1.6 & 25.6 & 33.0 & 29.0 & 34.6 \\
\hline & 平均 & 45 & 2.2 & 15.5 & 18.5 & 20.0 & 20.7 \\
\hline \multirow{3}{*}{$\begin{array}{l}\text { 授 } \\
\text { 乳 } \\
\text { 期 }\end{array}$} & 15 & 6.9 & 2.0 & 7.3 & 9.8 & 14.2 & 11.8 \\
\hline & 16 & 4.8 & 3.9 & 3.9 & 5.9 & 8.7 & $\begin{array}{r}9.8 \\
\end{array}$ \\
\hline & 平均 & 5.9 & 2.9 & 5.6 & 7.9 & 11.5 & 10.8 \\
\hline
\end{tabular}


$1-\alpha=0.95$

\begin{tabular}{lr|c|c|c|c}
\hline & & 妊娠前期( 2) & 妊娠後期(12) & 授 乳 期( 2) & 全 平 均 (16) \\
\hline 糖 質 & $\mathrm{g}$ & 449.2 & $375.2 \pm 66.6$ & 499.1 & $400.0 \pm 58.9$ \\
蛋白質 & $\mathrm{g}$ & 90.5 & $82.5 \pm 15.7$ & 77.9 & $82.9 \pm 11.5$ \\
脂 質 & $\mathrm{g}$ & 38.5 & $33.1 \pm 8.7$ & 36.1 & $34.2 \pm 6.7$ \\
熱 量 & $\mathrm{Cal}$ & 2505 & $2129 \pm 322$ & 2633 & $2239 \pm 277$ \\
$\mathrm{~V} . \mathrm{A}$ & $\mathrm{I} . \mathrm{U}$ & 408 & $2390 \pm 1068$ & 1693 & $2055 \pm 799$ \\
$\mathrm{~V} . \mathrm{B}_{1}$ & $\mathrm{mg}$ & 1.67 & $1.19 \pm 0.28$ & 1.19 & $1.25 \pm 0.24$ \\
$\mathrm{~V} . \mathrm{B}$. & $\mathrm{mg}$ & 1.12 & $0.98 \pm 0.17$ & 1.28 & $1.04 \pm 0.18$ \\
$\mathrm{~V} . \mathrm{C}$ & $\mathrm{mg}$ & 111 & $102 \pm 29$ & 83 & $101 \pm 22$ \\
$\mathrm{P}$ & $\mathrm{mg}$ & 1446 & $1328 \pm 326$ & 1083 & $1312 \pm 242$ \\
$\mathrm{Ca}$ & $\mathrm{mg}$ & 654 & $627 \pm 240$ & 304 & $588 \pm 185$ \\
$\mathrm{Fe}$ & $\mathrm{mg}$ & 18.6 & $14.8 \pm 3.0$ & 9.8 & $14.6 \pm 2.7$ \\
蛋熱/総熱 & $\%$ & 14.2 & $14.5 \pm 2.4$ & 11.3 & $14.0 \pm 1.9$ \\
動蛋/総蛋 & $\%$ & 37.2 & $32.5 \pm 7.8$ & 38.8 & $33.9 \pm 6.1$ \\
\hline
\end{tabular}

其他の栄養素摂取量は妊娠後期!ニ於て特!こ不足しているものが多く, 日本人の妊産婦所要量に及ばない。 終りに, 御指導御校閲孛賜つた田村部長, 並にこの調査のために御援助御協力をいただいた牛込保健所の 中村栄養士及び牛込区助産婦会の方々!深く感謝の意を表する。

$$
\text { 文献 }
$$

1) 総理府資源調査会, 改訂日本食品標準成分表, (1954)

2）資源調査会報吾：日本人の栄養基準量 (1953)

抄 錄

\section{乳中ピタミン $\mathrm{B}_{p}$ の微生物学的測定}

M. E. Gregory (Brit, J, Nutrition, 8, 340, (1954) は動物の乳中ビタミン $\mathrm{B}_{12}$ を Lacto bacillus Leichmannii, Escherichria coli, Ochromonas malhamensis 用いて測定した。牛, 山羊, 豚, 最, 羊等の乳を人乳と比較したが, $\mathrm{B}_{12}$ は何れの場合もその結合をばなすためパパイン分 解が期まれ, 特に人乳と豚の乳て必要とする。他 の動物乳の場合にも最大測定值を得る!には, 測定 操作 (水て稀釈し, Cyanide ion 芭添加) の改良
が必要である。各乳中 $\mathrm{B}_{12}$ の平均含有量は, 牛 23 , 山羊 0.9. 人 0.3 , 豚 17 , 鼠 13.0 羊 $7.0 \mathrm{~m}$ Y-ccである 未加熱の牛乳孛殺菌試験管に, 接種直前に加えた 場合, L. leichmanniiの生育を抑へる未知生長阻 害因子の存在を暗示しているのは興味深い。乳を アルカリ処理すると総 $\mathrm{B}_{p}$ 括性を破壊し, $\mathrm{B}_{12}-$ sparing desoxyribosids 次乏赤す。幼児の $B_{12}$ 要求量は未だ確定されていない。Nutri. Reviews 3, 185, (1955)

(田村 敦) 